\section{Bark- and Peat-amended Spent Mushroom Compost for Containerized Culture of Shrubs}

\author{
Calvin Chong ${ }^{1}$, R.A. Cline ${ }^{1}$, and D.L. Rinker ${ }^{1}$ \\ Ontario Ministry of Agriculture, Food, and Rural Affairs, Horticultural \\ Research Institute of Ontario, Vineland Station, Ont. LOR 2EO, Canada
}

Additional index words. nursery production, woody plants, foliar nutrients, waste recycling, organic matter

\begin{abstract}
Four deciduous ornamental shrubs ['Coral Beauty' cotoneaster (Cotoneaster dammeri C.K. Schneid); Tartarian dogwood (Cornus alba L.); 'Lynwood' forsythia (Forsythia $\times$ intermedia Zab.); 'Variegata' weigela (Weigela florida Bunge A.D.C.)] were grown in trickle-fertigated containers. There were eight media consisting of $25 \%$ or $50 \%$ sphagnum peat or composted pine bark, $25 \%$ sand, and the remainder one of two sources of spent mushroom compost; four media with 509" peat or bark mixed with $50 \%$ spent mushroom compost; and a control medium of 10070 pine bark. Initially, higher than desirable salt levels in all compost-amended media were leached quickly (within 2 weeks of planting) and not detrimental to the species tested. Unlike cotoneaster, which showed no difference in growth (shoot dry weight) due to medium, dogwood, forsythia, and weigela grew significantly better in all compost-amended media than in the control. Growth of these three species was $20 \%$ greater in peat-based than in bark-based, compost-amended media. Dogwood and forsythia grew slightly more $(+8 \%)$ with spent mushroom compost based primarily on straw-bedded horse manure than with one based on a blend of strawbedded horse manure, wheat straw, and hay. The addition of sand $(25 \%)$ to a mixture of $50 \%$ peat or bark and $25 \%$ spent compost produced a medium with minimal compaction.
\end{abstract}

Research has suggested the potential of spent mushroom compost in the culture of field crops (Wuest, 1991), fruits (Robbins et al., 1986), vegetables (Maher, 1991; Male, 198 1; Wang et al., 1984), greenhouse crops (White, 1976), and foliage plants (Henny, 1979). However, the presence of high and potentially toxic salt levels in spent mushroom compost is largely responsible for its restricted use as a soil or potting amendment (Chong et al., 1991 b).

Chong et al. (1991a, 1991c) showed that many ornamental woody species grew well in trickle-fertigated containers amended with spent mushroom compost. There was little or no difference in performance of plants grown in media amended with freshly spent (excess salt level), leached (low salt level), or aged (intermediate salt level) composts due to rapid leaching of salts (Chong et al., 1991a, 1991b, 1991c). Growth of most species tested increased with or was minimally affected by increasing proportions of spent compost $\leq 100 \%$ by volume. However, these studies with containers were limited to binary mix-

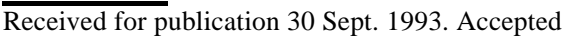
for publication 23 Jan. 1994. Appreciation is extended to Willowbrook Nurseries, Ont., Canada, for supplying unrooted cuttings, and to Greenwood Mushroom Farms and Leaver Mushroom Co. for supplying the spent composts. Bob Hamersma and Debbie Norton provided technical assistance. The cost of publishing this paper was defrayed in part by the payment of page charges. Under postal regulations, this paper therefore must be hereby marked advertisement solely to indicate this fact.

'Research Scientist. tures of bark and spent mushroom compost. Furthermore, mixtures with two-thirds or more by volume of spent compost compacted excessively by the end of the growing season. Our study evaluated a wider range of amendment combinations with spent mushroom compost restricted to amounts (25\% or $50 \%$ ) more desirable in commercial container nursery culture.

\section{Materials and Methods}

Stem cuttings ( 10-12 cm long) of 'Coral Beauty' cotoneaster, Tartarian dogwood, 'Lynwood' forsythia, and 'Variegata' weigela

Table 1. Changes in electrical conductivity in bark- and peat-based (BB and PB, respectively) media during the growing season measured in 1 medium :2 water extracts $(\mathrm{v} / \mathrm{v})$.

\begin{tabular}{|c|c|c|c|c|c|c|c|c|}
\hline \multirow[b]{2}{*}{ Media $^{z}$} & \multirow[b]{2}{*}{ Composition } & \multicolumn{7}{|c|}{$\mathrm{EC}\left(\mathrm{dS} \cdot \mathrm{m}^{-1}\right)$} \\
\hline & & 3 May & 7 Mayy & 8 May & 15 May & 22 May & 27 June & 24 Aug. \\
\hline Control & $100 \mathrm{~B}$ & $0.4^{x}$ & 0.1 & 0.1 & 0.1 & 0.1 & 0.1 & 0.1 \\
\hline \multicolumn{9}{|c|}{ Greenwood } \\
\hline \multirow{3}{*}{$\mathrm{BB}$} & $50 \mathrm{~B}: 50 \mathrm{SMC}$ & 2.8 & 1.5 & 1.5 & 1.2 & 0.7 & 0.3 & 0.2 \\
\hline & $50 \mathrm{~B}: 25 \mathrm{SMC}: 25 \mathrm{~S}$ & 1.3 & 1.1 & 0.7 & 0.5 & 0.3 & 0.1 & 0.1 \\
\hline & $25 \mathrm{~B}: 50 \mathrm{SMC}: 25 \mathrm{~S}$ & 2.6 & 1.8 & 0.9 & 0.8 & 0.5 & 0.3 & 0.2 \\
\hline \multirow[t]{3}{*}{ PB } & $50 \mathrm{P}: 50 \mathrm{SMC}$ & 4.0 & 4.0 & 2.3 & 2.0 & 1.0 & 0.3 & 0.3 \\
\hline & $50 \mathrm{P}: 25 \mathrm{SMC}: 25 \mathrm{~S}$ & 2.2 & 1.6 & 1.4 & 1.1 & 0.5 & 0.3 & 0.2 \\
\hline & $25 \mathrm{P}: 50 \mathrm{SMC}: 25 \mathrm{~S}$ & 4.6 & 3.1 & 2.0 & 1.2 & 0.9 & 0.4 & 0.2 \\
\hline \multicolumn{9}{|l|}{ Leaver } \\
\hline \multirow[t]{3}{*}{$\mathrm{BB}$} & $50 \mathrm{~B}: 50 \mathrm{SMC}$ & 2.3 & 2.0 & 1.4 & 0.5 & 0.4 & 0.3 & 0.2 \\
\hline & $50 \mathrm{~B}: 25 \mathrm{SMC}: 25 \mathrm{~S}$ & 1.2 & 1.0 & 0.6 & 0.3 & 0.2 & 0.1 & 0.1 \\
\hline & $25 \mathrm{~B}: 50 \mathrm{SMC}: 25 \mathrm{~S}$ & 2.5 & 1.5 & 1.2 & 0.5 & 0.3 & 0.2 & 0.2 \\
\hline \multirow[t]{3}{*}{ PB } & $50 \mathrm{P}: 50 \mathrm{SMC}$ & 4.0 & 2.9 & 2.2 & 1.6 & 0.8 & 0.4 & 0.3 \\
\hline & $50 \mathrm{P}: 25 \mathrm{SMC}: 25 \mathrm{~S}$ & 1.6 & 1.6 & 0.9 & 0.8 & 0.2 & 0.3 & 0.2 \\
\hline & $25 \mathrm{P}: 50 \mathrm{SMC}: 25 \mathrm{~S}$ & 2.9 & 2.5 & 1.7 & 0.9 & 0.3 & 0.4 & 0.3 \\
\hline SEM & & 0.2 & 0.6 & 0.6 & 0.6 & 0.4 & 0.1 & 0.1 \\
\hline
\end{tabular}

${ }^{\mathrm{B}}=$ pine bark; $\mathrm{P}=$ peat; $\mathrm{SMC}=$ spent mushroom compost; $\mathrm{S}=$ sand.

'Date of planting.

"Each datum is an average of duplicate samples on 3 May and of eight samples on each date thereafter. were rooted during Summer 1989 in Multipot no. 3 plastic plug trays $\left(99 \mathrm{~cm}^{3} /\right.$ plug; Ropak Capilano, Ont., Canada) and overwintered in a minimum-heated $(-5 \mathrm{C})$ polyethylene-covered greenhouse.

Two sources of spent mushroom compost, analyzed and identified as A (Leaver Mushroom Co. ) and $\mathrm{C}$ (Greenwood Mushroom Farms) by Chong et al. (1991 c), were used in this study. The Leaver source was derived primarily from straw-bedded horse manure and the Greenwood source from a blend of straw-bedded horse manure, wheat straw, and hay. Composts used to grow the commercial mushroom Agaricus bisporus (Lange) Imbach were taken from farms at the end of the cropping cycle (end of Apr. 1990), immediately after harvested shelves or trays had been steampasteurized.

Between 1 and 3 May, 6-liter $(21 \mathrm{~cm}$ in diameter and $21 \mathrm{~cm}$ deep) plastic nursery containers were filled with media consisting of 1 ) $25 \%$ or $50 \%$ (by volume) of nonamended sphagnum peat or nonamended composted pine bark (2-cm mesh size); 2) 25\% sand from a local quarry (Fonthill, Ont.); 3 ) $25 \%$ or $50 \%$ of one of the two sources of spent mushroom compost; 4) media with $50 \%$ peat or bark mixed with $50 \%$ spent mushroom compost; and 5) the control medium, which was $100 \%$ pine bark. Filled containers were held in a barn until transfer to the container nursery at the Horticultural Research Institute, Ontario, between 3 and 4 May.

Rooted cuttings (12- to 15 -cm-tall liners) were planted on 7 May. Cotoneaster and weigela containers were spaced $45 \times 45 \mathrm{~cm}$ and the other species $60 \times 45 \mathrm{~cm}$, each arranged in a separate randomized completeblock design with five replications of all 13 treatments (Table 1) and four plants per plot. Between 4 and 5 May, there was a total of 19 $\mathrm{mm}$ of rainfall (0.4 liter of water per container). On 7 May, each container was watered manually to run-off with $\approx 1$ liter of water before planting and 0.5 liter after planting. Thereafter, plants were trickle-irrigated daily with 1 liter of water per container twice per day 
and fertilized through the irrigation system three times weekly with $200 \mathrm{mg}$ N/liter using 20.0N-8.7P-16.6K water-soluble fertilizer with micronutrients (Plant Products, Brampton, Ont.) as described by Chong et al. (1991a, 1991c).

On 3 May, duplicate samples of each unmixed organic amendment (bark, peat, and two sources of compost) and each experimental medium were analyzed in 1 medium : 2 water extracts $(\mathrm{v} / \mathrm{v})$ for $\mathrm{pH}$ and electrical conductivity (EC), a measure of the soluble salts concentration (Davidson and Mecklenburg, 198 1). At planting (7 May), and at increasing intervals during the season $(8,15$, and 2 May; 27 June; and 24 Aug.), $\mathrm{pH}$ and EC were analyzed from medium samples collected (7to $12-\mathrm{cm}$ depth) from each treatment and species in two of the four replicates on each date. Triplicate samples of each medium taken at the start of the experiment were analyzed for bulk density (air dry-weight basis), air pore space, water pore space, and total pore space (air + water pore space) (Chong et al., 1991a).

In mid-August, recently matured leaves were sampled, dried, ground, and analyzed for total N, P, K, Ca, Mg, Mn, Fe, and Zn (Chong et al., 199 la). In mid-September, the width (cotoneaster) or height (all other species) of each plant was measured and shoot (stem with leaves) dry weights were determined. Compaction of the medium in each container was measured and expressed as vertical distance (in centimeters) from the container rim.

\section{Results and Discussion}

There were differences in the physical properties of the media at the start of the experiment (Fig. 1). The bulk density of all media with sand was 2 to 3 times greater than that of media without sand. The range in water pore space (moisture retention capacity) in peatbased media ( $45 \%$ to $65 \%$ ) was greater than in bark-based media (39\% to $42 \%$ ) and was inversely related to the air pore space (aeration porosity) (peat-based, 9\% to $15 \%$; bark-based, $17 \%$ to $31 \%$ ).

The $\mathrm{pH}$ values of unmixed bark (6.0) and peat (3.9) and low EC $\left(0.4 \mathrm{dS} \cdot \mathrm{m}^{-1}\right)$ in both amendments were different than the unmixed spent mushroom composts, which were alkaline (Greenwood, $\mathrm{pH}$ 8.5; Leaver, $\mathrm{pH} 8.1$ ) and had elevated EC (Greenwood, $8.5 \mathrm{dS} \cdot \mathrm{m}^{-1}$; Leaver $\left.8.0 \mathrm{dS} \cdot \mathrm{m}^{-1}\right)$. Previous results indicate high EC are caused by high concentrations of $\mathrm{K}, \mathrm{Cl}, \mathrm{Na}$, and $\mathrm{Mg}$ (Chong et al., $1991 \mathrm{c}$ ).

The initial EC levels in all experimental media were low (3 May, 4 days before planting) (Table 1). On 7 May (date of planting), after some leaching, all media containing mushroom compost had EC between 1.0 and $4.0 \mathrm{dS} \cdot \mathrm{m}^{-1}$. EC levels were lowest in media with $25 \%$ mushroom compost $\left(1.0-1.6 \mathrm{dS} \cdot \mathrm{m}^{-1}\right)$ and highest in media with $50 \%$ peat (2.9-4.0 $\left.\mathrm{dS} \cdot \mathrm{m}^{-1}\right)$ (Table 1).

On 22 May ( 2 weeks after planting), the EC in all media had declined to $\leq 1.0 \mathrm{dS} \cdot \mathrm{m}^{-1}$ (Table 1), a value considered safe for container plant culture (Davidson and Mecklenburg, 1981). As in previous studies, the relatively brief

\section{GREenWood Leaver}
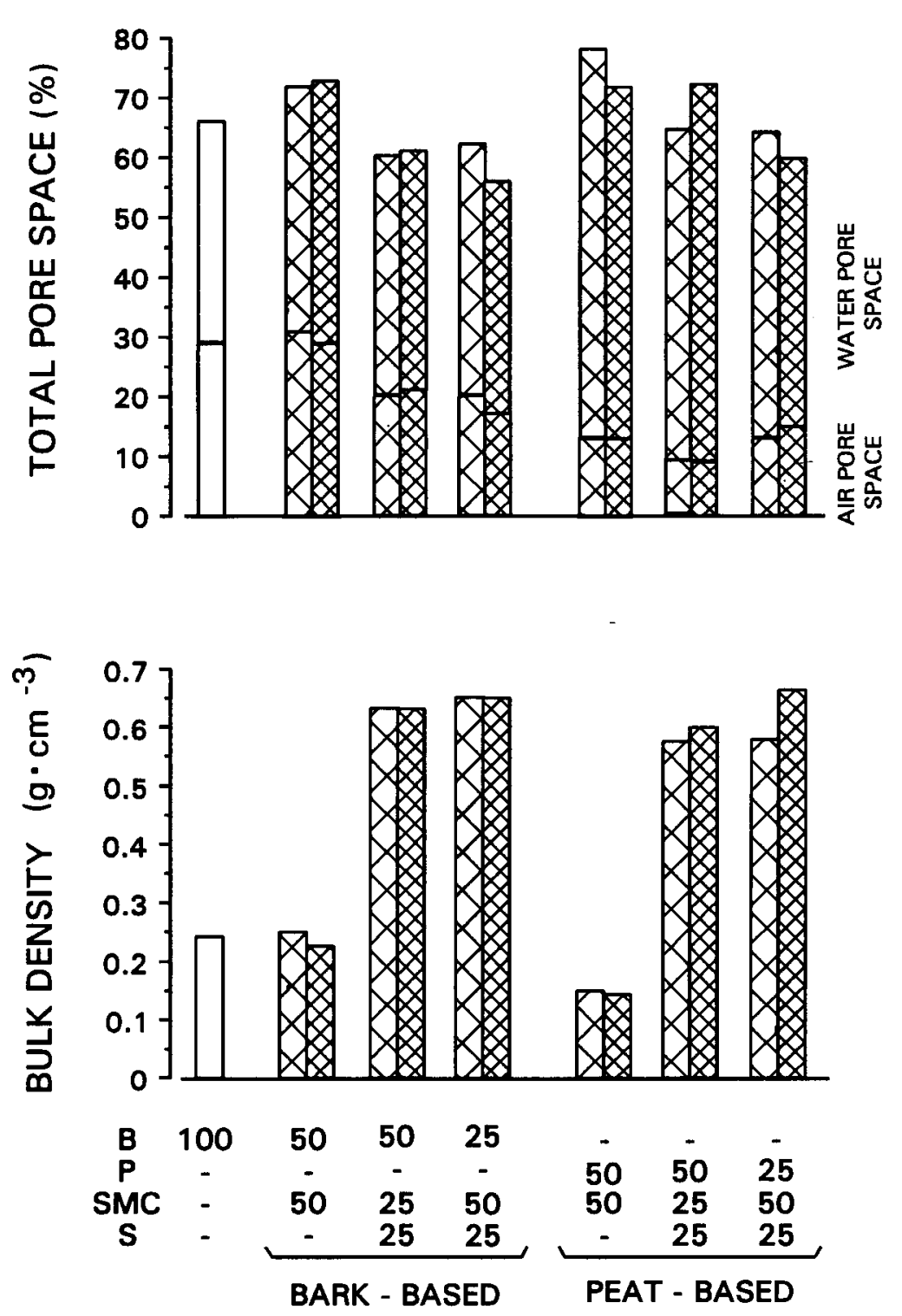

Fig. 1. Physical properties of bark-based and peat-based, spent mushroom compost media at planting. B = pine bark; $\mathrm{P}=$ peat; $\mathrm{SCM}=$ spent mushroom compose $\mathrm{S}=$ sand. Legend: Greenwood, wider crosshatching; Leaver, narrower cross-hatching. SEM: bulk density, 0.03; total pore space, 6; air pore space, 3 ; and water pore space, 5 .

Table 2. Analysis of variance of shoot dry weight (grams/plant) of nursery crops grown in bark- and peatbased media amended with spent mushroom compost.

\begin{tabular}{|c|c|c|c|c|c|}
\hline \multirow[b]{2}{*}{ Source } & \multirow[b]{2}{*}{ df } & \multicolumn{4}{|c|}{ Mean squares } \\
\hline & & Cotoneaster & Dogwood & Forsythia & Weigela \\
\hline Media & 12 & $217^{\mathrm{NS}}$ & $5390^{* *}$ & $3217^{* *}$ & $570^{* *}$ \\
\hline Replication & 4 & $97^{\mathrm{NS}}$ & $4523^{* *}$ & $4334^{* *}$ & $976^{* *}$ \\
\hline Error & 48 & 129 & 1097 & 398 & 191 \\
\hline \multicolumn{6}{|l|}{ Contrasts } \\
\hline Control vs. all others & & & $* *$ & $* *$ & ** \\
\hline Bark-base $^{2}$ vs. peat-based & & & $* *$ & $* *$ & ** \\
\hline Greenwood vs. Leaver & & & $*$ & * & $\mathrm{N} \mathrm{S}$ \\
\hline $25 \%$ compost vs. $50 \%$ compost & & & $\mathrm{N} \mathrm{S}$ & $\mathrm{N} \mathrm{S}$ & $\mathrm{N} \mathrm{S}$ \\
\hline $25 \%$ peat vs. $50 \%$ peat & & & $\mathrm{NS}$ & $\mathrm{N} \mathrm{S}$ & * \\
\hline $25 \%$ bark VS. $50 \%$ bark & & & $\mathrm{NS}$ & $* *$ & N S \\
\hline No sand ${ }^{2}$ vs. $25 \%$ sand & & & $\mathrm{N} \mathrm{S}$ & $\mathrm{N} \mathrm{S}$ & N S \\
\hline
\end{tabular}

${ }^{2}$ The $100 \%$ bark (control) treatment is excluded.

${ }^{\mathrm{Ns}, * * *}$ Nonsignificant or significant at $P \leq 0.05$ or 0.01 , respectively. 
exposure (2 weeks) to higher EC levels under these cultural conditions did not have a detrimental effect on the plants (Chong et al., 1991a, 1991b, 1991c). The $\mathrm{pH}$ in all compostamended media ranged from 7.4 to 7.9 at planting and varied little $( \pm 0.3)$ throughout the growing season (data not shown). The $\mathrm{pH}$ of the $100 \%$ bark (control) medium increased from 6.5 (start) to 7.2 (end).

Irrespective of these differences, our management system produced vigorous plants that were of marketable quality at harvest. Analysis of variance (Table 2) showed that cotoneaster grew equally well in all treatments. Width of cotoneaster and height of the other species also were unaffected by media (data not shown).

There were notable differences in response of dogwood, forsythia, and weigela to the various media. Contrast analysis (Table 2) indicated greater shoot dry weight for these species in all compost-amended media than in the control medium (Fig. 2). Growth of all three species was $20 \%$ greater in peat-based compost media.

Despite differences in the composition of the two sources of spent mushroom compost, there were few or no differences in plant response attributable to the compost source. Although both dogwood and forsythia grew slightly more $(+8 \%)$ in media with Leaver spent mushroom compost than with Greenwood compost, weigela growth was unaffected by the compost source (Table 2; Fig. 2). Amount of compost $(25 \%$ or $50 \%)$ had no effect on dogwood, forsythia, or weigela growth. However, weigela grew $12 \%$ more in media with $50 \%$ peat than with $25 \%$ peat. Forsythia grew $13 \%$. more in media with the lower rate of bark. The presence or absence of sand had no influence on growth.

There were variations in leaf macro- and microelemental composition (data not shown) attributable to differences in the media, but all nutrients were present in acceptable levels (Ontario Ministry of Agriculture and Food, 1992); differences were small, except for Mn. In three (cotoneaster, forsythia, and weigela) of the four species, leaf Mn accumulated more in leaves of plants grown in peat-based media (141-150 $\left.\mathrm{mg} \cdot \mathrm{kg}^{-1}\right)$ than in plants grown in bark-based media $\left(60-74 \mathrm{mg} \cdot \mathrm{kg}^{-1}\right)$, but the reason for this finding is unknown.

Both Eames (1977) and Lemaire et al. (1985) comment on the "lack of stability" (compaction) of spent mushroom compost as an amendment - a characteristic we also observed (Chong et al., 1991a). When mixed with sand and peat, compaction of spent mushroom compost-amended media was minimal (Eames, 1977). In our study, compaction of all spent mushroom compost-amended media was significantly greater $(1.4-2.5 \mathrm{~cm})$ than compaction in the $100 \%$ bark (control) medium $(1.2 \mathrm{~cm})$ (Fig. 3). Although not contributing to growth, sand in combination with $25 \%$ spent mushroom compost (50 bark: 25 spent mushroom compost: 25 sand and 50 peat: 25 spent mushroom compost : 25 sand) (Fig. 3) produced compost-amended media with the least compaction. In this regard, compaction in the

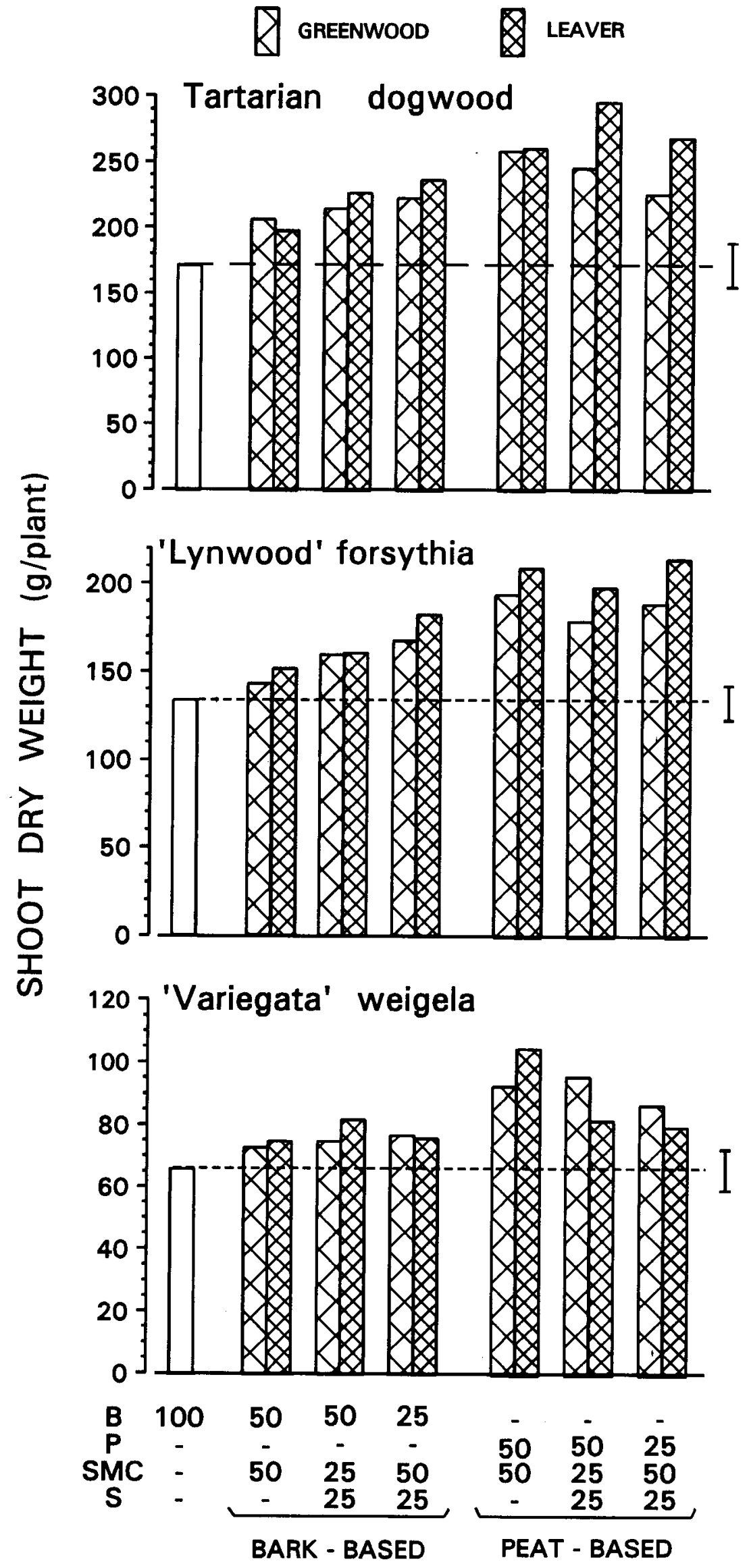

Fig. 2. Shoot dry weight of three nursery crops grown in bark- and peat-based, spent mushroom compost media. $\mathrm{B}=$ pine bark; $\mathrm{P}=$ peat; $\mathrm{SCM}=$ spent mushroom compost; $\mathrm{S}=$ sand. Legend: Greenwood, wider cross-hatching; Leaver, narrower cross-hatching. Horizontal broken lines represent growth in the 100'\% bark (control) medium. Vertical bars represent SEM: dogwood, 33; forsythia, 20; and weigela, 14. 


\section{GREENWOOD

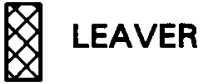

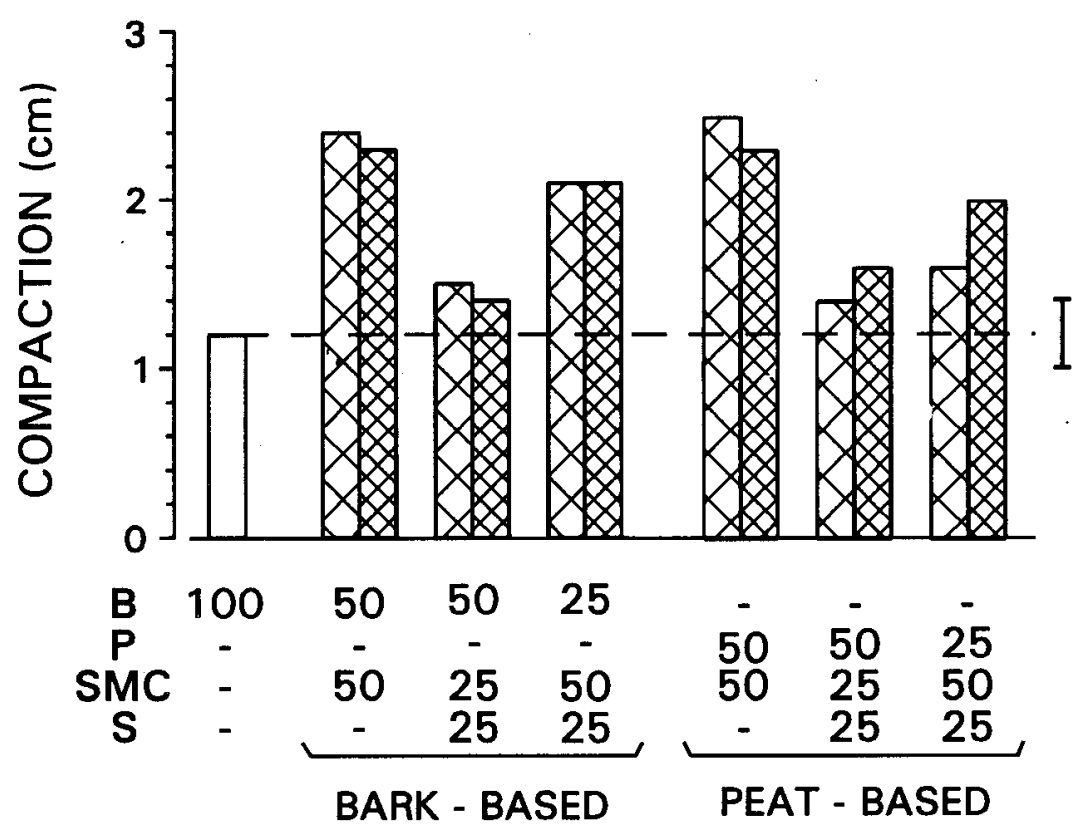

Fig. 3. Compaction of bark-based and peat-based, spent mushroom compost media at harvest. Data were averaged over all species, $\mathrm{B}=$ pine bark; $\mathrm{P}=$ peat; $\mathrm{SCM}=$ spent mushroom compost; $\mathrm{S}=$ sand. Legend: Greenwood, wider cross-hatching; Leaver, narrower cross-hatching. Horizontal broken lines represent growth in the $100 \%$ bark (control) medium. The vertical bar represents SEM $=0.4$.

sand-based formulations was comparable to the $100 \%$ bark control and confirmed the observations of Eames (1977). As shown in earlier studies (Chong et al., 1991a, 1991c), good growth occurred (Fig. 2) regardless of the degree of compaction in the compostamended media (Fig. 3). Furthermore, with the smaller amount of spent mushroom compost used in this study $(25 \%$ or $50 \%)$ compared to earlier studies $(\leq 100 \%)$ (Chong et al., 1991a, 1991 b), the degree of compaction observed was relatively small and may be of little or no practical significance.
This study provides additional new information on the successful recycling of spent mushroom compost in nursery container culture. Our results demonstrate that various barkand peat-based amendments combined with $25 \%$ or $50 \%$ spent mushroom compost prometed growth of four container-grown, deciduous, nursery shrubs. Similar or better growth occurred in peat-based rather than in bark-based media. The addition of sand $(25 \%)$ to a mixture of $50 \%$ peat or bark and $25 \%$ spent compost produced a medium with minimal compaction.

\section{Literature Cited}

Chong, C., R.A. Cline, D.L. Rinker, and O.B. Allen. 1991a. Growth and mineral nutrient status of containerized woody species in media amended with spent mushroom compost. J. Amer. Sot. Hort. Sci. 116:242-247.

Chong, C., R.A. Cline, D.L. Rinker, and B. Hamersma. 1991 b. An overview of reutilization of spent mushroom compost in nursery container culture. Landscape Trades 13(11): 14-18.

Chong, C., D.L. Rinker, and R.A. Cline. 1991c. A comparison of five spent mushroom composts for container culture of ornamental shrubs. Mushroom Sci. 13(Pt.2):637-644.

Davidson, H. and R. Mecklenburg. 1981. Nursery management. Prentice-Hall, Englewood Cliffs, N.J.

Eames, A.G. 1977. Could spent mushroom compost be used for container shrubs? Mushroom J. 52:114. (Abstr.)

Henny, B.K. 1979. Production of six foliage crops in spent mushroom compost potting mixes. Proc. Fla. State Hort. Soc. 92:330-332,

Lemaire, F., A. Dartigues, and L.M. Riviere. 1985. Properties of substrate made with spent mushroom compost. Acts Hort. 172: 13-29.

Maher, M.J. 1991. Spent mushroom compost (SMC) as a nutrient source in peat-based potting substrates. Mushroom Sci. 12(Pt.1):645-650.

Male, R.T. 1981. The use of spent mushroom compost in vegetable production. Mushroom Sci. 11(Pt.1):111-121.

Ontario Ministry of Agriculture and Food. 1992. Production recommendations for nursery and landscape plants. Publ. 383.

Robbins, S. H., T.L. Reghetti, E. Fallahi, A.R. Dixon, and M.H, Chaplin. 1986. Influence of trenching, soil amendments, and mulching on the mineral content, growth, yield, and quality of "Italian" prunes, Commun. Soil Sci. Plant Anal. 17:457471 .

Wang, H.S., V.I. Lohr, and D.L. Coffey. 1984. Spent mushroom compost as a soil amendment for vegetables. J. Amer. Soc. Hort. Sci. 109:698702 .

White, J.W. 1976. Mushroom casing soil and sphagnum moss peat: Growing media for Easter lilies, Mushroom News 24(6): 17-19.

Wuest, P.J. 1991. Development of procedure for using and storing spent mushroom compost to reduce the risk of lowering water quality, Pennsylvania Dept. Agr., Final Res. Proj. Rpt., University Park. 